\title{
Control of size and physical properties of graphene oxide by changing the oxidation temperature
}

\author{
Dongwoo Kang and Hyeon Suk Shin* \\ Two Dimensional Carbon Materials Center and Interdisciplinary School of Green Energy, Ulsan National Institute of Science and \\ Technology, Ulsan 689-798, Korea
}

\author{
Article Info \\ Received 31 August 2011 \\ Accepted 10 December 2011 \\ *Corresponding Author \\ E-mail: shin@unist.ac.kr \\ Tel: $+82-52-217-2311$

\section{Open Access} \\ DOI: http://dx.doi.org/ \\ 10.5714/CL.2012.13.1.039 \\ This is an Open Access article distributed \\ under the terms of the Creative Commons \\ Attribution Non-Commercial License \\ (http://creativecommons.org/licenses/ \\ by-nc/3.0/) which permits unrestricted \\ non-commercial use, distribution, and \\ reproduction in any medium, provided \\ the original work is properly cited.
}

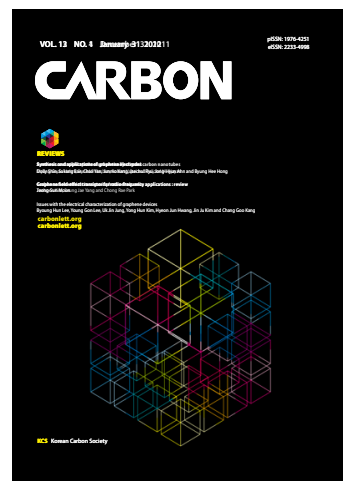

http://carbonlett.org

pISSN: 1976-4251

elSSN: 2233-4998

Copyright $\odot$ Korean Carbon Society

\begin{abstract}
The size and the physical properties of graphene oxide sheets were controlled by changing the oxidation temperature of graphite. Graphite oxide (GO) samples were prepared at different oxidation temperatures of $20^{\circ} \mathrm{C}, 27^{\circ} \mathrm{C}$ and $35^{\circ} \mathrm{C}$ using a modified Hummers' method. The carbonto-oxygen $(\mathrm{C} / \mathrm{O})$ ratio and the average size of the $\mathrm{GO}$ sheets varied according to the oxidation temperature: 1.26 and $12.4 \mu \mathrm{m}$ at $20^{\circ} \mathrm{C}, 1.24$ and $10.5 \mu \mathrm{m}$ at $27^{\circ} \mathrm{C}$, and 1.18 and $8.5 \mu \mathrm{m}$ at $35^{\circ} \mathrm{C}$. This indicates that the $\mathrm{C} / \mathrm{O}$ ratio and the average size of the graphene oxide sheets respectively increase as the oxidation temperature decreases. Moreover, it was observed that the surface charge and optical properties of the graphene oxide sheets could be tuned by changing the temperature. This study demonstrates the tunability of the physical properties of graphene oxide sheets and shows that the properties depend on the functional groups generated during the oxidation process.
\end{abstract}

Key words: graphene, graphene oxide, graphite oxide, degree of oxidation

\section{Introduction}

Graphene is a monolayer of carbon that forms a two-dimensional hexagonal $\mathrm{sp}^{2}$ hybridized structure. Since the discovery of exfoliated free-standing graphene from bulk graphite using the "scotch tape" method, graphene has attracted much attention not only in fundamental research fields but also in various application fields due to its outstanding and unique electronic and mechanical properties [1-4]. In particular, it has the potential to serve as a key component in energy storage devices such as fuel cells and as a substitute for indium tin oxide in transparent conducting electrodes.

Considerable effort has been made thus far to prepare graphene, and various methods have been reported, including mechanical exfoliation of graphite using scotch tape [1], chemically exfoliated graphene oxide and reduced graphene oxide ( $\mathrm{rGO})[5,6]$, exfoliation of graphite in organic solvents or acid without any oxidation process [7-10], the growth of a large-area graphene layer on metal using chemical vapor deposition (CVD) [11-13], and epitaxial growth on a SiC substrate [14,15]. While large-area or the scalable production of high-quality graphene has not been realized to date, CVD and chemical exfoliation methods are promising in terms of mass production for real applications [16,17].

The physical properties of graphene oxide, such as the electrical properties, band gap energy, transparency, optical properties, and surface charge, can be determined by the type and quantity of the functional groups on the graphene oxide sheets. Moreover, the size of the graphene oxide sheets is affected by the degree of oxidation of the graphite; functional groups and defect sites, which are increased by a high degree of oxidation, can lead to a breakdown of the graphene oxide sheets during the exfoliation process. Furthermore, functional groups such as epoxy and hydroxyl groups on the basal plane of graphene oxide can act as nucleation sites for the growth of inorganic materials such as $\mathrm{TiO}_{2}$, silica, and nanocrystals of $\mathrm{Ni}, \mathrm{Co}$, and $\mathrm{Fe}$, which show different sizes and shapes according to the degree of oxidation 
of the graphene oxide substrate [18-20]. Therefore, control of graphite oxidation is necessary for various applications of graphene oxide sheets. It was recently reported that graphene oxide sheets with different oxygen content amounts can be prepared simply by changing the starting graphite, oxidation time, and amount of oxidant, providing variation in the size distribution, electrical conductivity, and energy band gap [21-24]. However, no correlation between the properties or size of graphene oxide sheets and the oxidation temperature has been reported thus far.

Herein, we synthesized graphene oxide sheets at different oxidation temperatures using the modified Hummers' method and investigated their carbon-to-oxygen $(\mathrm{C} / \mathrm{O})$ ratios, size distributions, surface charges, and optical properties. The $\mathrm{C} / \mathrm{O}$ atomic ratio was 1.18 at $35^{\circ} \mathrm{C}, 1.24$ at $27^{\circ} \mathrm{C}$ and 1.26 at $20^{\circ} \mathrm{C}$. This means that more functional groups including oxygen are introduced in the graphene oxide sheet at higher temperatures. After exfoliation, the average lateral size of the graphene oxide sheets was $12.4 \mu \mathrm{m}$ at $20^{\circ} \mathrm{C}, 10.8 \mu \mathrm{m}$ at $27^{\circ} \mathrm{C}$, and $8.3 \mu \mathrm{m}$ at $35^{\circ} \mathrm{C}$. Furthermore, we show that the surface charge and optical properties of the graphene oxide sheets are related to the degree of oxidation.

\section{Experimental}

\subsection{Materials}

Natural graphite having an average particle size of $74 \mu \mathrm{m}$ was purchased from Bay Carbon (Bay City, MI, USA). Chemical reagents used for the synthesis of graphite oxide (GO), including phosphorus pentoxide $\left(\mathrm{P}_{2} \mathrm{O}_{5}\right)$ and potassium permanganate $\left(\mathrm{KMnO}_{4}\right)$, were purchased from Sigma-Aldrich. Sulfuric acid $\left(\mathrm{H}_{2} \mathrm{SO}_{4}\right)$ was obtained from Merck Chemicals (Darmstadt, Germany).

\subsection{Preparation of GO}

GO was prepared from purified natural graphite (SP-1, Bay Carbon) by the modified Hummers' method [25]. The graphite powder $(20 \mathrm{~g})$ was put into an $80^{\circ} \mathrm{C}$ solution of concentrated $\mathrm{H}_{2} \mathrm{SO}_{4}(30 \mathrm{~mL}), \mathrm{K}_{2} \mathrm{~S}_{2} \mathrm{O}_{8}(10 \mathrm{~g})$ and $\mathrm{P}_{2} \mathrm{O}_{5}(10 \mathrm{~g})$. The resultant dark blue mixture was thermally isolated and allowed to cool to room temperature over a period of $6 \mathrm{~h}$. The mixture was then carefully diluted with distilled water, filtered, and washed on the filter until the rinse water $\mathrm{pH}$ became neutral. The product was dried in air at ambient temperatures overnight. This pre-oxidized graphite was then subjected to oxidation by the Hummers' method. The pre-oxidized graphite powder $(20 \mathrm{~g})$ was put into cold concentrated $\mathrm{H}_{2} \mathrm{SO}_{4}(460 \mathrm{~mL}) . \mathrm{KMnO}_{4}(60 \mathrm{~g})$ was added gradually while stirring and cooling the mixture, during which the temperature of the mixture was not allowed to reach $20^{\circ} \mathrm{C}$. The mixture was then stirred at $35^{\circ} \mathrm{C}$ for $2 \mathrm{~h}$, and distilled water $(920 \mathrm{~mL})$ was added. The oxidation temperature was changed to $20^{\circ} \mathrm{C}$ and $27^{\circ} \mathrm{C}$ for the other samples. After $15 \mathrm{~min}$, the reaction was terminated by the addition of a large amount of distilled water $(2.8 \mathrm{~L})$ and a $30 \% \mathrm{H}_{2} \mathrm{O}_{2}$ solution $(50 \mathrm{~mL})$, after which the color of the mixture changed to bright yellow. The mixture was filtered and washed with a 1:10 $\mathrm{HCl}$ solution $(5 \mathrm{~L})$ in order to remove metal ions. The GO product was suspended in distilled water to give a viscous, brown dispersion, which was subjected to dialysis to remove metal ions and acids completely. All GO suspensions, obtained under different oxidation temperatures, were very stable in water. Exfoliation of the above GO to graphene oxide was carried out by dilution of the GO dispersion $(3.5 \mathrm{~mL})$ with deionized water $(35 \mathrm{~mL})$ followed by vigorous stirring at $15000 \mathrm{rpm}$ with a homogenizer for $15 \mathrm{~min}$. The resulting homogeneous yellow-brown sol, of which the concentration was $0.3 \mathrm{mg} / \mathrm{mL}$, was stable for at least a few months.

\subsection{Measurements and characterization}

The average size and morphology of the graphene oxide sheets were measured by scanning electron microscopy (SEM; FEI, USA) and atomic force microscopy (AFM; Veeco, USA). To measure the degree of oxidation of the GO, the element contents were calculated for carbon, hydrogen, oxygen, nitrogen and sulphur by an element analyzer, a Flash 2000 device (Thermo Scientific, The Netherlands). UV/Vis absorption spectra of the graphene oxide solution samples were measured by a Cary 5000 (Varian, USA) in a range of $200-800 \mathrm{~nm}$, and the surface charges (zeta potential) of the samples were measured by the Nano ZS system (Malvern, UK) in a range of $\mathrm{pH}$ 2.5-10.

\section{Results and Discussion}

\subsection{Degree of oxidation of graphite}

The degree of oxidation of graphite at different temperatures was estimated by an elemental analysis of the final GO samples. The contents of each element and the $\mathrm{C} / \mathrm{O}$ atomic ratio for the GO samples are summarized in Table 1 . The oxygen contents of GO were $44.55 \mathrm{wt} \%$ at $20^{\circ} \mathrm{C}, 47.16 \mathrm{wt} \%$ at $27^{\circ} \mathrm{C}$, and 49.92 $\mathrm{wt} \%$ at $35^{\circ} \mathrm{C}$, indicating that more functional groups including oxygen were generated on the graphene oxide sheets at high temperatures. The degree of oxidation is directly related to the $\mathrm{C} / \mathrm{O}$ atomic ratio based on the carbon and oxygen contents. The $\mathrm{C} / \mathrm{O}$ ratio of $\mathrm{GO}$ was calculated to be 1.18 at $35^{\circ} \mathrm{C}$, which is the oxidation temperature used during the normal modified Hummers' method. However, the $\mathrm{C} / \mathrm{O}$ ratio of the other $\mathrm{GO}$ samples was 1.24 at $27^{\circ} \mathrm{C}$ and 1.26 at $20^{\circ} \mathrm{C}$. As the oxidation temperature was increased, the $\mathrm{C} / \mathrm{O}$ atomic ratio decreased. This result is due to the formation of more functional groups during the oxidation process at higher temperatures.

Table 1. Element analysis of GO samples obtained at different oxidation temperatures

\begin{tabular}{rccc} 
& GO-35 & GO-27 & GO-20 \\
\hline Carbon $(w t \%)$ & 44.09 & 45.51 & 44.55 \\
\hline Oxygen (wt $\%)$ & 49.92 & 48.93 & 47.16 \\
\hline Hydrogen (wt\%) & 3.30 & 2.96 & 3.02 \\
\hline Sulphur (wt\%) & 3.04 & 1.71 & 2.57 \\
\hline C/O atomic ratio & 1.18 & 1.24 & 1.26 \\
\hline
\end{tabular}

GO: graphite oxide, C/O: carbon-to-oxygen.

${ }^{\mathrm{a}} \mathrm{GO}$ sample oxidized at $35^{\circ} \mathrm{C}$.

${ }^{\mathrm{b}} \mathrm{GO}$ sample oxidized at $27^{\circ} \mathrm{C}$.

'GO sample oxidized at $20^{\circ} \mathrm{C}$ 

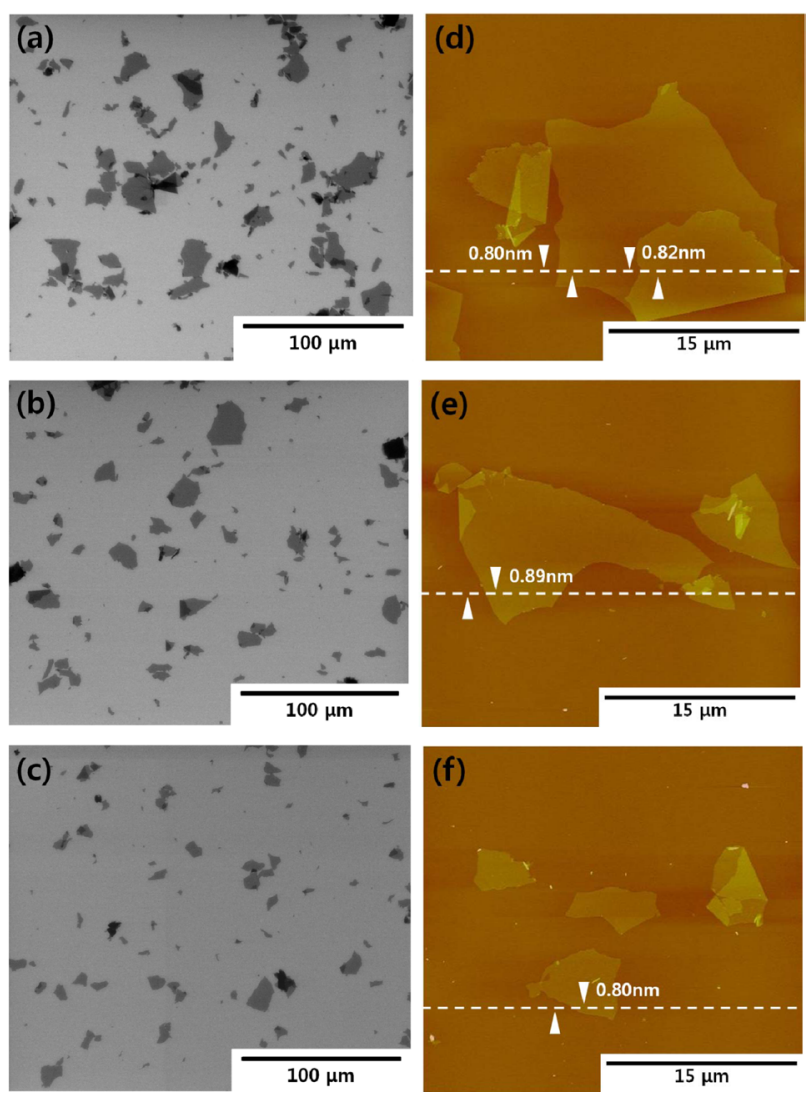

Fig. 1. (a) (c) Scanning electron microscopy images and (d) (f) atomic force microscopy images of graphene oxide sheets: (a) and (d) for graphite oxide oxidized at $20^{\circ} \mathrm{C}$, (b) and (e) at $27^{\circ} \mathrm{C}$, and (c) and (f) at $35^{\circ} \mathrm{C}$.
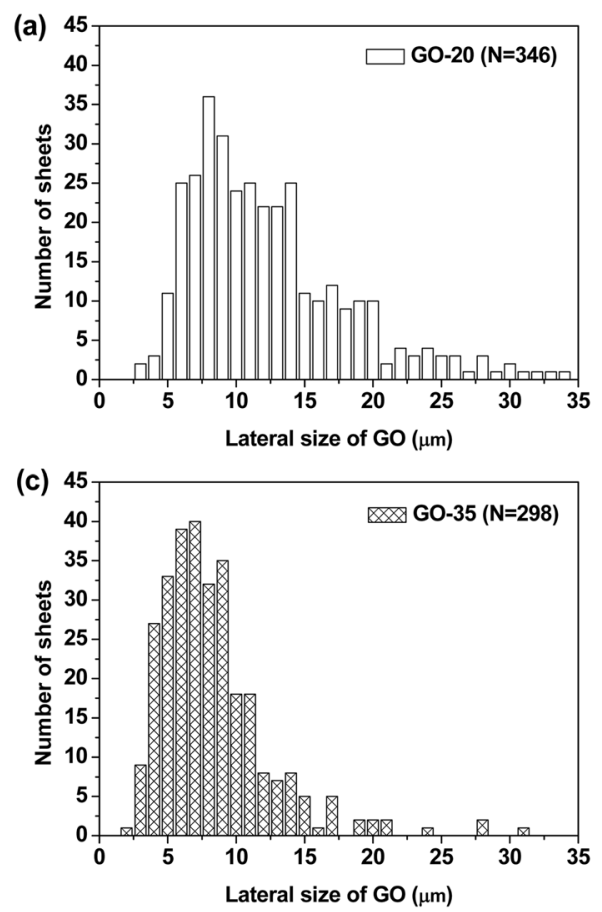

\subsection{Size distribution of graphene oxide sheets}

Figs. 1a-f exhibit SEM and AFM images of graphene oxide sheets obtained at different oxidation temperatures. The AFM height profiles in Figs. 1d-f show that the exfoliated graphene oxide sheets are single layers with a thickness of 0.8-0.9 nm. The size distribution of the graphene oxide sheets, with more than 300 sheets for each sample, is shown in Figs. 2a-c. It was obtained by measuring the size of the graphene oxide sheets in the SEM images. The average size of the graphene oxide sheets was calculated to be $12.4 \mu \mathrm{m}$ at $20^{\circ} \mathrm{C}, 10.8 \mu \mathrm{m}$ at $27^{\circ} \mathrm{C}$, and $8.3 \mu \mathrm{m}$ at $35^{\circ} \mathrm{C}$, as shown in Fig. $2 \mathrm{~d}$. The smaller size of the graphene oxide sheets at a higher temperature is attributed to the generation of more functional groups and defect sites during the oxidation process. Additionally, $\pi$-conjugation may be reduced due to the decrease in the sheet size by the functional groups and defect sites. The change of the $\pi$-conjugation was investigated by UV/Vis absorption spectroscopy. According to the results, the band at $233 \mathrm{~nm}$ in the case of graphene oxide at $20^{\circ} \mathrm{C}$ (mild oxidation) shifts slightly to a shorter wavelength in the case of graphene oxide at $35^{\circ} \mathrm{C}$ (Fig. 3). The blue shift for highly oxidized graphene oxide is due to the reduced $\pi-\pi$ conjugated domain size as a result of the increased functional groups and defect sites within the graphene oxide sheets [23,24].

\subsection{Comparison of the surface charge via zeta- potential measurement}

The reactivity of nano-sized materials is closely related to their size, shape, and surface properties. In the case of gra-
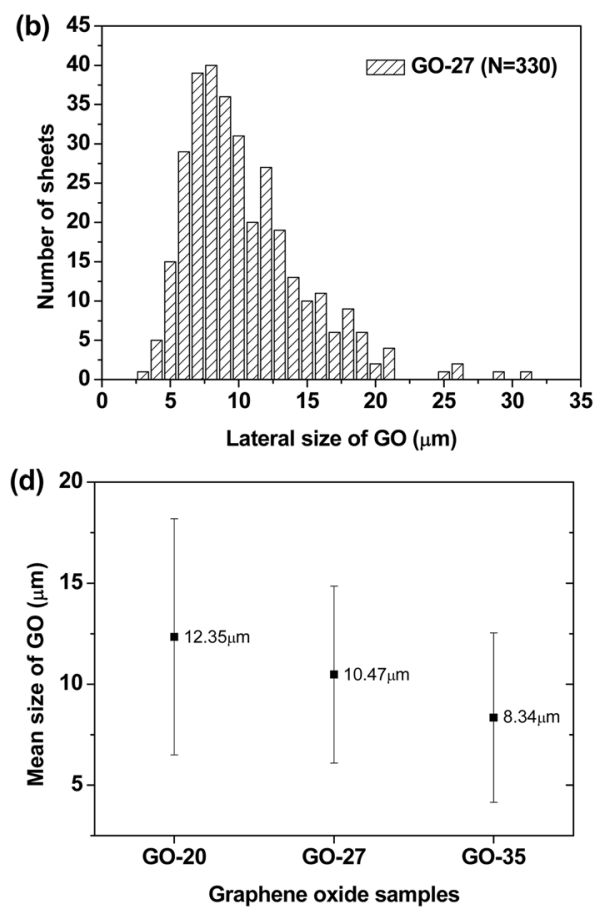

Fig. 2. Histograms for size distributions of graphene oxide sheets oxidized at $20^{\circ} \mathrm{C}(\mathrm{a}), 27^{\circ} \mathrm{C}(\mathrm{b})$, and $35^{\circ} \mathrm{C}(\mathrm{c})$, and (d) the average size of graphene oxide sheets at different oxidation temperatures. 


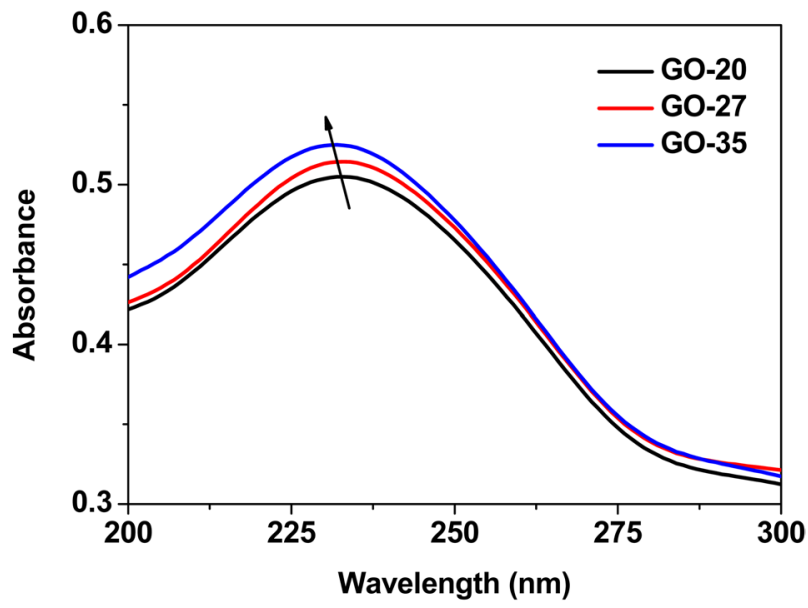

Fig. 3. UV-Vis absorption spectra of a graphene oxide suspension in water obtained at different oxidation temperatures (the concentration of each sample is $0.075 \mathrm{~g} / \mathrm{mL}$ ).

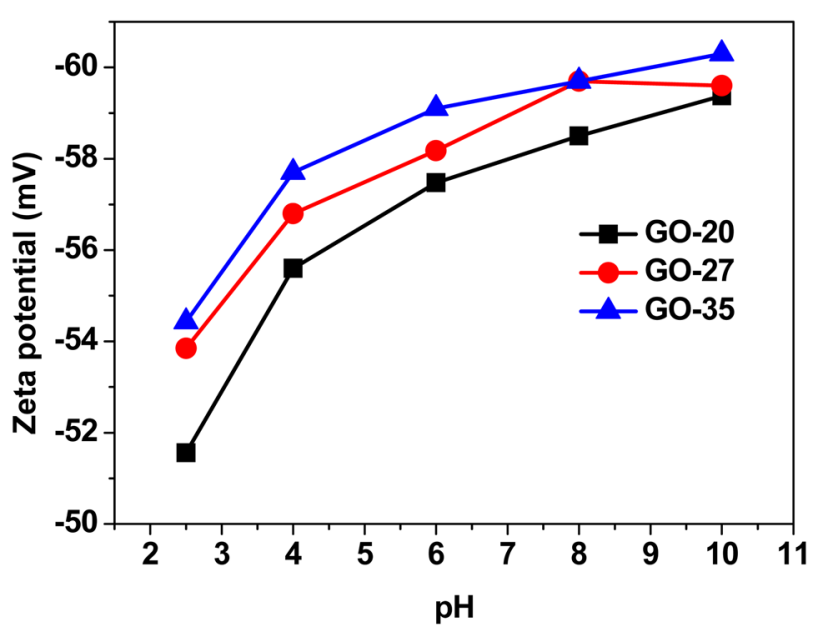

Fig. 4. Zeta potential measurement of graphene oxide suspensions obtained at different oxidation temperatures.

phene oxide, surface properties such as the surface charge may depend upon the quantity and type of functional groups on the graphene oxide surface. During the oxidation process, functional groups (mainly the epoxy group on the basal plane and hydroxyl and carboxylic groups at the edge side) are introduced to the graphene oxide sheets. The functional groups at the edges of the graphene oxide sheets can weakly develop negative charges in the solution due to deprotonation, yielding a hydrophilic nature. Negatively charged graphene oxide sheets were investigated by zeta potential measurements. Fig. 4 shows that the zeta potential values of the graphene oxide sheets increase with the oxidation temperature in a wide range of $\mathrm{pH}$ values, from 2.5-10 in this case. The graphene oxide suspension sample obtained at $35^{\circ} \mathrm{C}$ showed the highest negative value at all $\mathrm{pH}$ levels. Given these results, it is considered that the graphene oxide sheets obtained at $35^{\circ} \mathrm{C}$ possess more functional groups with negative charges. This result is consistent with the results gained with the average size and $\mathrm{C} / \mathrm{O}$ ratio of the present $\mathrm{GO}$ samples.

\section{Conclusions}

We successfully controlled the size and physical properties, specifically the optical properties and surface charge, of graphene oxide sheets by changing the oxidation temperature by means of the modified Hummers' method. From SEM images of graphene oxide sheets prepared under different oxidation temperatures, the average size was $12.4 \mu \mathrm{m}$ at $20^{\circ} \mathrm{C}, 10.5 \mu \mathrm{m}$ at $27^{\circ} \mathrm{C}$, and $8.3 \mu \mathrm{m}$ at $35^{\circ} \mathrm{C}$. As the oxidation temperature was increased, the oxygen content increased. Thus, the $\mathrm{C} / \mathrm{O}$ atomic ratio decreased due to the creation of more functional groups and additional defect sites at high oxidation temperatures. Furthermore, the band at $233 \mathrm{~nm}$ in the UV-Vis absorption spectra was slightly blue-shifted, indicating a reduced $\pi$-conjugated domain size. According to zeta potential measurements, a highly oxidized graphene oxide suspension at $35^{\circ} \mathrm{C}$ revealed the highest negative values. These results indicate that the size and physicochemical characteristics of graphene oxide sheets can be tuned by the degree of oxidation. Therefore, this study demonstrates the tunability of the properties of graphene oxide and rGO, a feature that is necessary for actual applications.

\section{Acknowledgments}

This work was supported by the Technology Innovation Program funded by the Ministry of Knowledge Economy (MKE, Korea), and LG electronics.

\section{References}

[1] Novoselov KS, Geim AK, Morozov SV, Jiang D, Zhang Y, Dubonos SV, Grigorieva IV, Firsov AA. Electric field in atomically thin carbon films. Science, 306, 666 (2004). http://dx.doi.org/10.1126/ science. 1102896.

[2] Zhang Y, Tan YW, Stormer HL, Kim P. Experimental observation of the quantum Hall effect and Berry's phase in graphene. Nature, 438, 201 (2005). http://dx.doi.org/10.1038/nature04235.

[3] Son YW, Cohen ML, Louie SG. Half-metallic graphene nanoribbons. Nature, 444, 347 (2006). http://dx.doi.org/10.1038/nature 05180 .

[4] Wang HM, Wu YH, Ni ZH, Shen ZX. Electronic transport and layer engineering in multilayer graphene structures. Appl Phys Lett, 92, 053504 (2008). http://dx.doi.org/10.1063/1.2840713.

[5] Stankovich S, Dikin DA, Dommett GHB, Kohlhaas KM, Zimney EJ, Stach EA, Piner RD, Nguyen ST, Ruoff RS. Graphenebased composite materials. Nature, 442, 282 (2006). http://dx.doi. org/10.1038/nature04969.

[6] McAllister MJ, Li JL, Adamson DH, Schniepp HC, Abdala AA, Liu J, Herrera-Alonso M, Milius DL, Car R, Prud'homme RK, Aksay IA. Single sheet functionalized graphene by oxidation and thermal expansion of graphite. Chem Mater, 19, 4396 (2007). http:// dx.doi.org/10.1021/cm0630800.

[7] Blake P, Brimicombe PD, Nair RR, Booth TJ, Jiang D, Schedin F, Ponomarenko LA, Morozov SV, Gleeson HF, Hill EW, Geim AK, Novoselov KS. Graphene-based liquid crystal device. Nano Lett, 8, 1704 (2008). http://dx.doi.org/10.1021/n1080649i. 
[8] Hernandez Y, Nicolosi V, Lotya M, Blighe FM, Sun Z, De S, McGovern IT, Holland B, Byrne M, Gun'ko YK, Boland JJ, Niraj P, Duesberg G, Krishnamurthy S, Goodhue R, Hutchison J, Scardaci V, Ferrari AC, Coleman JN. High-yield production of graphene by liquid-phase exfoliation of graphite. Nature Nanotechnol, 3, 563 (2008). http://dx.doi.org/10.1038/nnano.2008.215.

[9] Hamilton CE, Lomeda JR, Sun Z, Tour JM, Barron AR. High-yield organic dispersions of unfunctionalized graphene. Nano Lett, 9, 3460 (2009). http://dx.doi.org/10.1021/n19016623.

[10] Behabtu N, Lomeda JR, Green MJ, Higginbotham AL, Sinitskii A, Kosynkin DV, Tsentalovich D, Parra-Vasquez ANG, Schmidt J, Kesselman E, Cohen Y, Talmon Y, Tour JM, Pasquali M. Spontaneous high-concentration dispersions and liquid crystals of graphene. Nature Nanotechnol, 5, 406 (2010). http://dx.doi.org/10.1038/ nnano.2010.86.

[11] Reina A, Jia X, Ho J, Nezich D, Son H, Bulovic V, Dresselhaus MS, Jing K. Large area, few-layer graphene films on arbitrary substrates by chemical vapor deposition. Nano Lett, 9, 30 (2009). http://dx.doi.org/10.1021/nl801827v.

[12] Chae SJ, Güneş F, Kim KK, Kim ES, Han GH, Kim SM, Shin H, Yoon SM, Choi JY, Park MH, Yang CW, Pribat D, Lee YH. Synthesis of large-area graphene layers on poly-nickel substrate by chemical vapor deposition: wrinkle formation. Adv Mater, 21, 2328 (2009). http://dx.doi.org/10.1002/adma.200803016.

[13] Kim KS, Zhao Y, Jang H, Lee SY, Kim JM, Ahn JH, Kim P, Choi JY, Hong BH. Large-scale pattern growth of graphene films for stretchable transparent electrodes. Nature, 457, 706 (2009). http:// dx.doi.org/10.1038/nature07719.

[14] Berger C, Song Z, Li X, Wu X, Brown N, Naud C, Mayou D, Li T, Hass J, Marchenkov AN, Conrad EH, First PN, De Heer WA. Electronic confinement and coherence in patterned epitaxial graphene. Science, 312, 1191 (2006). http://dx.doi.org/10.1126/science. 1125925.

[15] Emtsev KV, Bostwick A, Horn K, Jobst J, Kellogg GL, Ley L, McChesney JL, Ohta T, Reshanov SA, Rohrl J, Rotenberg E, Schmid AK, Waldmann D, Weber HB, Seyller T. Towards wafer-size graphene layers by atmospheric pressure graphitization of silicon carbide. Nature Mater, 8, 203 (2009). http://dx.doi. org/10.1038/nmat2382.

[16] Bae S, Kim H, Lee Y, Xu X, Park JS, Zheng Y, Balakrishnan J, Lei T, Ri Kim H, Song YI, Kim YJ, Kim KS, Ozyilmaz B, Ahn JH, Hong BH, Iijima S. Roll-to-roll production of 30-inch graphene films for transparent electrodes. Nature Nanotechnol, 5, 574 (2010). http://dx.doi.org/10.1038/nnano.2010.132.

[17] Yamaguchi H, Eda G, Mattevi C, Kim H, Chhowalla M. Highly uniform $300 \mathrm{~mm}$ wafer-scale deposition of single and multilayered chemically derived graphene thin films. ACS Nano, 4, 524 (2010). http://dx.doi.org/10.1021/nn901496p.

[18] Williams G, Seger B, Kamt PV. TiO2-graphene nanocomposites. UV-assisted photocatalytic reduction of graphene oxide. ACS Nano, 2, 1487 (2008). http://dx.doi.org/10.1021/nn800251f.

[19] Yang S, Feng X, Wang L, Tang K, Maier J, Mullen K. Graphenebased nanosheets with a sandwich structure. Angew Chem Int Ed, 49, 4795 (2010). http://dx.doi.org/10.1002/anie.201001634.

[20] Wang H, Robinson JT, Diankov G, Dai H. Nanocrystal growth on graphene with various degrees of oxidation. J Am Chem Soc, 132, 3270 (2010). http://dx.doi.org/10.1021/ja100329d.

[21] Wu ZS, Ren W, Gao L, Liu B, Jiang C, Cheng HM. Synthesis of high-quality graphene with a pre-determined number of layers. Carbon, 47, 493 (2009). http://dx.doi.org/10.1016/j.carbon.2008.10.031.

[22] Jin M, Jeong HK, Yu WJ, Bae DJ, Kang BR, Lee YH. Graphene oxide thin film field effect transistors without reduction. J Phys D: Appl Phys, 42, 135109 (2009). http://dx.doi.org/10.1088/00223727/42/13/135109.

[23] Luo J, Cote LJ, Tung VC, Tan ATL, Goins PE, Wu J, Huang J. Graphene oxide nanocolloids. J Am Chem Soc, 132, 17667 (2010). http://dx.doi.org/10.1021/ja1078943.

[24] Zhang L, Liang J, Huang Y, Ma Y, Wang Y, Chen Y. Size-controlled synthesis of graphene oxide sheets on a large scale using chemical exfoliation. Carbon, 47, 3365 (2009). http://dx.doi.org/10.1016/j. carbon.2009.07.045.

[25] Hummers WS Jr, Offeman RE. Preparation of graphitic oxide. J Am Chem Soc, 80, 1339 (1958). 